\title{
2011年東北地方太平洋沖地震による 地殼変動からの回復過程の考察
}

\author{
三神 厚 1 神山 眞 2 \\ 1正会員 東海大学教授 工学部土木工学科（†259-1292 神奈川県平塚市北金目4-1-1） \\ E-mail: atsushi.mikami@tokai.ac.jp \\ 2フェロー会員 東北工業大学名誉教授（干982-8577 宮城県仙台市太白区八木山香澄町35-1） \\ E-mail: mk_kamiyama@jcom.home.ne.jp
}

\begin{abstract}
東北地方太平洋沖地震によって東北地方の広域で地盤の沈降が生じ, 港湾施設は非常に使いづらい状態 となった，岸壁を嵩上げするなどの方策が講じられたが，地震後の隆起で逆に高くなりすぎて使いづらく なった漁港も現れた。同様なことは昭和南海地震の際の高知市でも起きており, 長期にわたる浸水被害に 悩まされた。

本研究はGEONETデータを用いて東北地方太平洋沖地震の際の地殼変動に伴う広域地盤の沈降からの回 復過程を考察するものである. 検討の結果, 本震後すぐに隆起に転じた場所と, 本震後もしばらく沈降が 続いた後, 隆起に転じた場所があることや, 本震後すぐに隆起に転じた場所ではその回復過程が指数関数 を用いて良好に表現されること, 指数関数の形状を確定する時定数の值が収束するには 1 年から 3 年程度要 することなどがわかった。
\end{abstract}

Key Words : GEONET, crustal movement, The 2011 off the Paicific coast of Tohoku Earthquake, recovery process

\section{1. はじめに}

平成23年（2011年）東北地方太平洋沖地震によって東 北地方の広い範囲で地盤の沈降が生じた．図-1は石巻市 渡波地区内の漁港施設の様子を撮影したものであるが, 満潮時には海面が岸壁天端すれすれまで到達するように なり漁港施設が非常に使いづらい状況となった．また市 街地では浸水してしまうため，ポンプによる排水を余儀 なくされた．使いら゙らくなった漁港に対し，沈降した分 だけ岸壁を嵩上げするなどの方策が講じられたが，その 後の地盤の隆起で，逆に高くなり寸ぎて使用が不便にな った漁港も現れた1).

同様なことが1946年昭和南海地震の際にも起きていた. 沢村2)によって高知市は約 $120 \mathrm{~cm}$ 沈下したと報告されてい る. 高知市は，津波と広域地盤沈降と堤防の決壊によっ てもたらされた浸水被害に長期にわたり悩まされた（図 -2).

南海トラフを震源とする地震の来襲が危惧されている が，1946年昭和南海地震と同様，広域的な地殼変動が起 きるものと予想される.このような地款変動に伴う問題 としては, 地震直後の地盤の沈降や隆起の問題に加えて,
沈降や隆起がどのような回復過程を辿り，またどの程度 回復するのか，などの問題があり，早期復興を実現する ための事前対策を考える上でいずれも不可欠な情報であ る.

このように地款変動に伴う地盤の沈降や隆起は, 昭和 南海地震, 東北地方太平洋沖地震とも発生したが, 昭和 南海地震当時とは異なり，現在では，全国に1200を超え

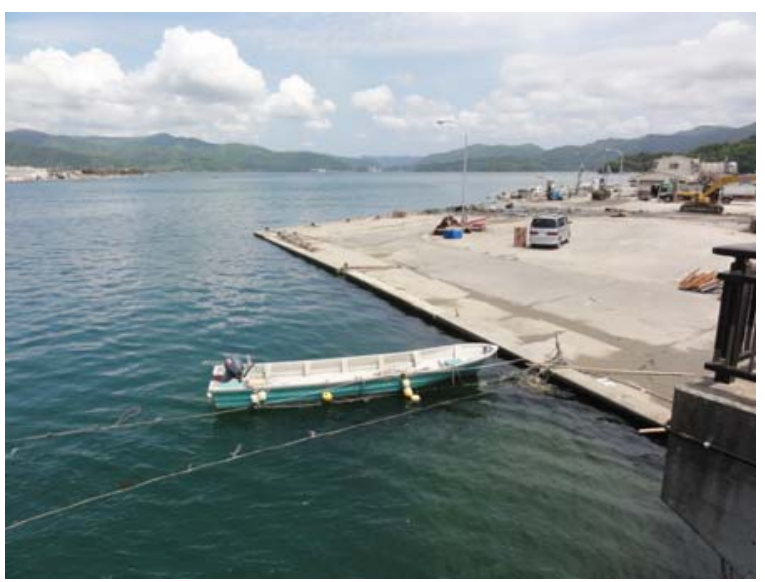

図-1 石巻市渡波地区の漁港施設の様子 (2011年 5 月 27 日著者撮影) 


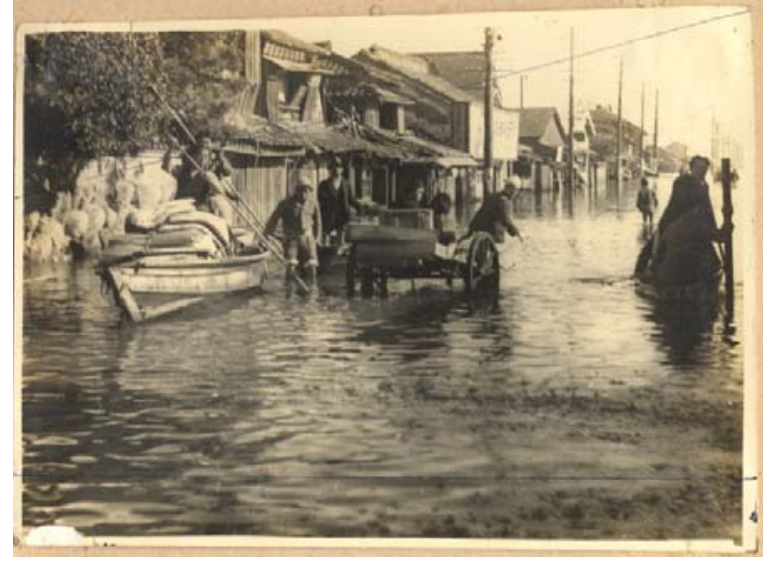

図-2＼cjkstart昭和南海地震の際の高知市の浸水被害 (昭和 21 年 12 月 21 日撮影，高知市提供)

る国土地理院の電子基準点があり, GPS観測により地款 変動がリアルタイムでモニタリングされている

（GEONET）。2011年3月11日の地震から4年が経過し, 東北地方各地の地殼変動からの回復過程が徐々に明らか になってきた. 東北地方太平洋沖地震の地款変動のメカ ニズムの解明は, 国土地理院や大学 (主に理学分野) で なされているが例えば3)4，基本的には上下変動の回復過程 は余効変動及びその後のプレート間カップリングの結果 である. 余効変動は地震後に観測される遷移的地殸変動 の総称であり $)$, 主な要因としてはプレート境界面上に おける余効すべりと上部マントルでの粘弾性緩和が挙げ られる. 本研究はGEONETデータを用いて, 東北地方太 平洋沖地震の際の地款変動に伴う地盤の沈降からの回復 過程を考察し，地款変動の将来予測へ向けた検討を行い たい.

\section{GEONETによる観測点と観測データ}

ここではGEONET観測の概要について述べるとともに, 本研究において着目した観測点, 用いたデータについて まとめる.

\section{(1) 観測の概要}

GEONETとは，GNSS Earth Observation Network Systemの 略で，国土地理院が展開するGPS連続観測システムのこ とで，日本全国に1200点を超える電子基準点がある. GNSS とはGlobal Navigation Satellite System（全球測位衛星 システム) で，GPS等の測位衛星システムの総称である。 複数の衛星を利用して電子基準点の位置を $\mathrm{cm}$ 誤差で 決定する.

提供されているデータの種類としては, リアルタイム データ（RINEX形式30秒サンプリング值）の他に，補正 され信頼性の高い測位プロダクトである日々の座標值
（F3解）がある。ここでは日々の座標值（F33解）を用い る.

\section{（2）東北地方から関東地方にかけて地殼変動の概要}

図-3に，東北地方太平洋沖地震による地震時地殸変動 を示す．なお，ここでは，日本時間で2011年3月10日 21:00 2011年3月12日21:00のF3データの差分量から東西, 南北, 上下方向の変位を算出している（日々の座標值で あるF3データは，24時間平均座標值を12:00(UTC)の值と して公開されている）。図左が水平変位で，星マークが 震源であるが，震源に向かって水平変位が生じているこ とがわかる，一方，右が本研究で着目寸る鉛直変位であ るが，東北地方の太平洋岸では概衩沈降しているのに対 し，日本海側では逆に隆起していることがわかる. 寸な わち, 震源付近では, 逆断層の上盤が隆起し, 少し離れ た東北地方太平洋岸で沈降, さらに離れた日本海側で隆 起と, 震源から離れる方向に隆起と沈降が交互に生じて いることが推察される.

一方, 図-4には東北地方太平洋沖地震の本震以降, 最 近に至るまでの水平と鉛直方向の変位分布を示している. 水平変位については本震以後も引き続き本震方向への変 位が続いている，鉛直変位については，東北地方太平洋 岸の多くの地域で隆起の傾向が見られ，宮城県を中心に その量が大きい，その一方で，岩手県の北部地域では沈 降した状態となっており（例えば，岩泉1観測点では地 震前に比べ約 $8.8 \mathrm{~cm}$ 沈降した状態となっている），未だ， 本震以前の水準に戻っていないことがわかる.

\section{（3）着目した観測点と検討に用いた観測データ}

本研究では港湾施設等の早期復興に主眼を置いている ので，ここでは東北地方の岩手県から福島県に至る太平 洋沿岸沿いの地殼変動に着目する. 図-5に着目したす心゙ ての観測点を示寸とともに，表-1にまとめる．これらの 観測点のうち，2011年3月11日前後で観測できていたも のを用いる．表-1には，データの有無も示している.

提供されるデータのF3解の内容としては, 各観測点の 地心座標值，緯度，経度，楕円体高であるが，ここでは 楕円体高を標高として近似的に用い，上下方向の変化を 考察する. なお本研究では，3月11日の本震前の基準と してそこからの変位量を検討するため, 本震前後の楕円 体高の差分（3/10と3/12の観測值の差分）をとる.この ため，楕円体高を標高の近似值として用いることにした。

\section{3. 沈降からの回復過程}

本研究では地震が発生した年の2011年の1月1日から本 震の4年後の2015年3月11日までのデータを用いる. 

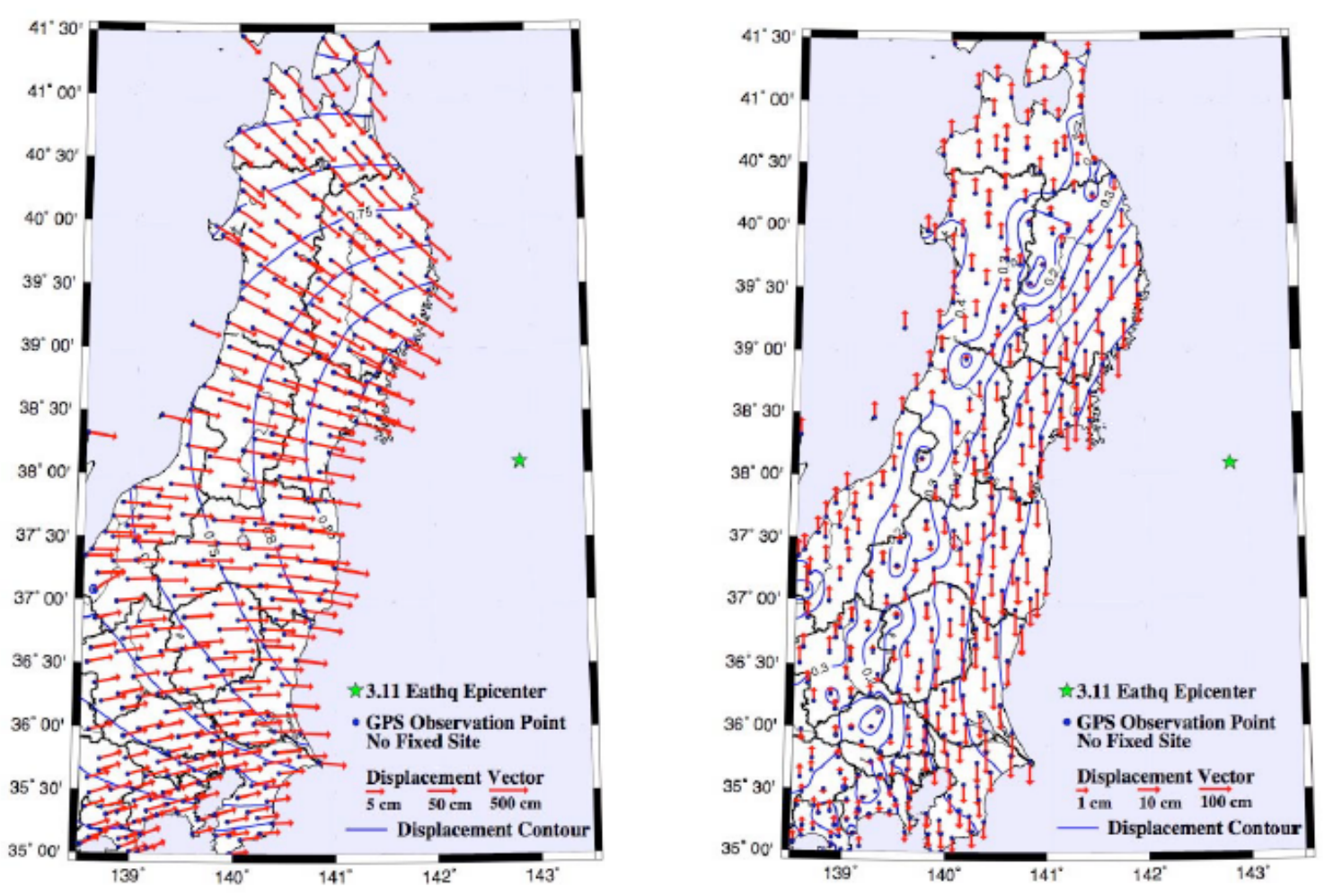

図-3 東北地方太平洋沖地震時の地款変動（出典 : Kamiyama etal.(2012) $)^{6}$ )
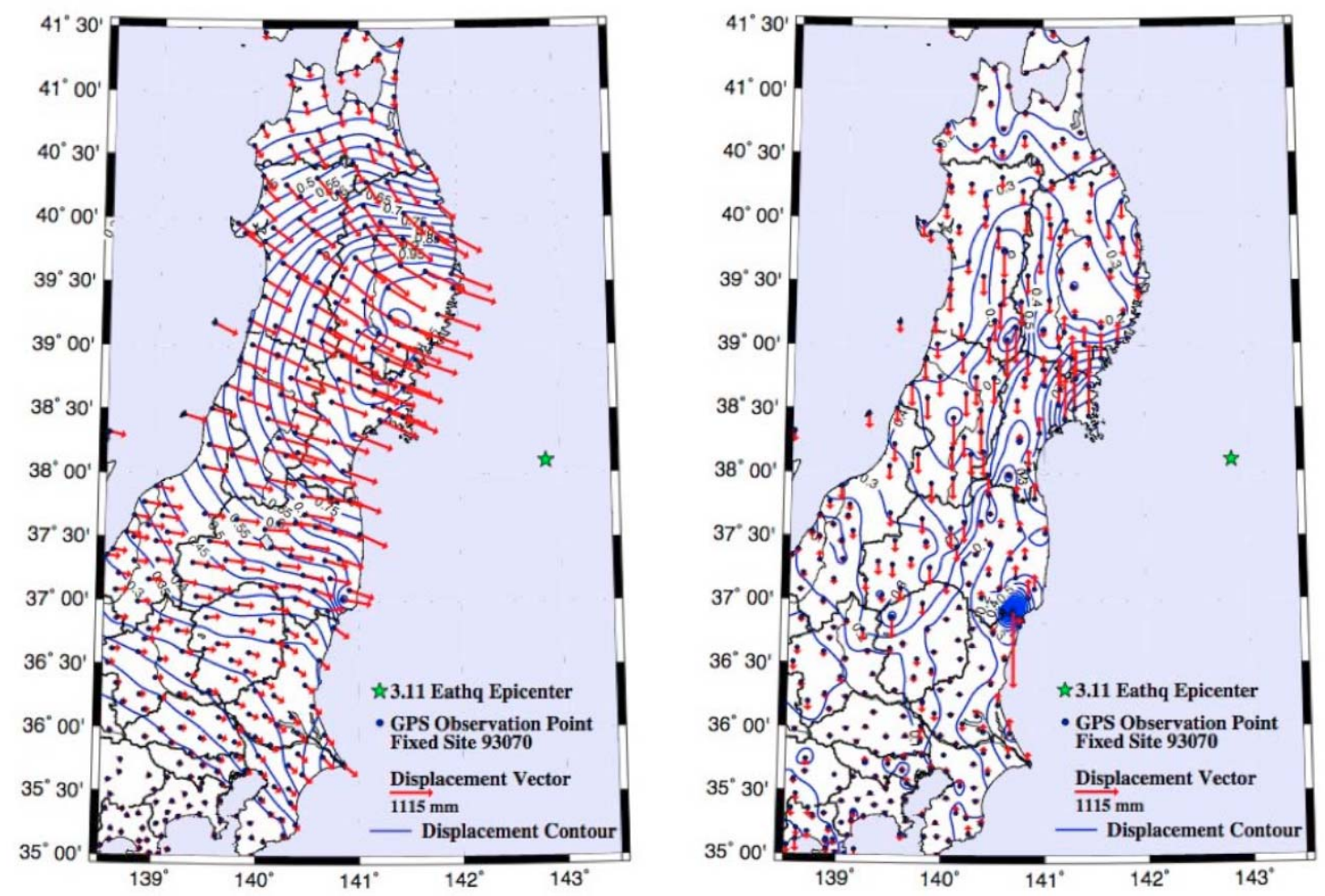

図-4 東北地方太平洋沖地震以降（2011.3.12）最近（2015.9.12）までの変位分布（出典 : 神山(2015) $\left.)^{7}\right)$

\section{（1） 本震前後の地款変動}

岩手から福島にかけての太平洋岸エリアでは3月11日 の本震によって基本的に沈降するが，本震直後から隆起
に転じるエリアと, 本震後もしばらく沈降が続いた後, 隆起に転じるエリアがある。これらの傾向の違いについ ては，表-1の回復過程の欄に示した．観測点番号 $1 \sim 9$ (岩手県北部) では，本震後もしばらく沈降が続いた後， 


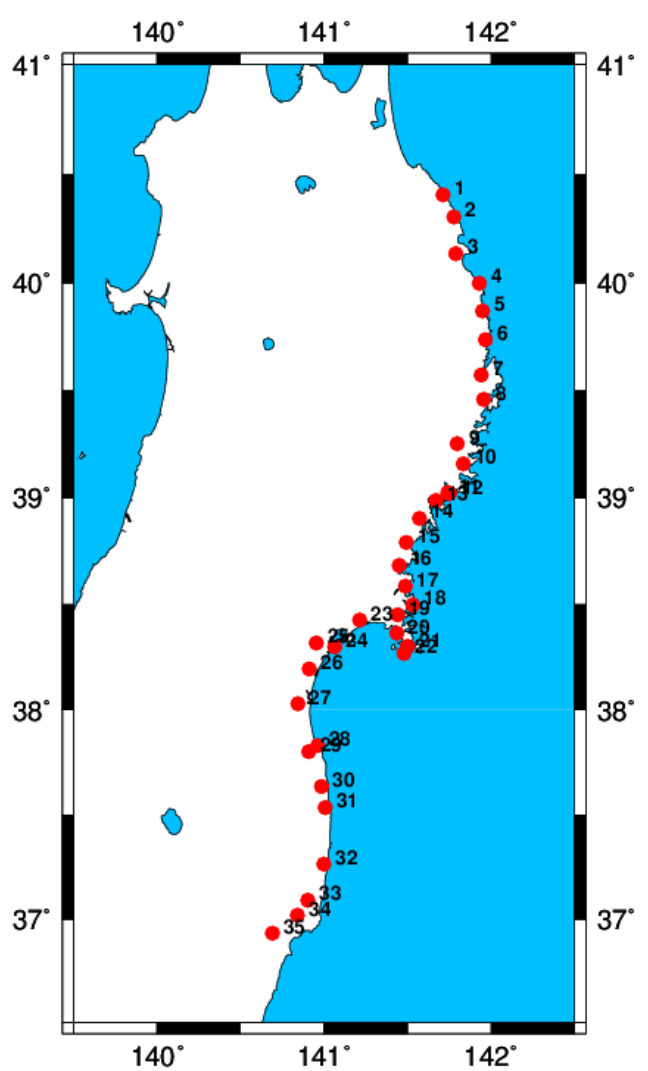

図-5 東北地方太平洋岸の GEONET 観測点

隆起に転じる．隆起の速度は非常にゆっくりである．典 型的な例として, 観測点番号7の宮古の地震前後の様子 を図-6に示す．横軸には2011年1月1日を起算日とした通 算日をとり，縦軸には標高の近似值として楕円体高を示 している. 本震の発生した3月11日は通算で70日目に相 当するが，図を見ると本震から 400 日以上（1年以上）に わたり沈下が続いていたことがわかる。これは本震でプ レートが滑ったところより深いところのプレート境界が ゆっくりと滑る余効すべり $)^{8}$ よるものと考えられる. その他, データからは北に行くほど回復の速度が遅いこ とも考察されたが，ここでは省略する.

一方，観測点9より南では，本震で沈下した後，すぐ に隆起に転じる傾向が見られる．このような挙動は，プ レートが滑ったことでマントルがゆっくり回復していく 粘弾性緩和8による現象と考えられる。代表例として矢 本（観測点番号23）の回復過程を図-7に示す．本震を境 に隆起に転じており, 宮古に比べて隆起の速度も速い。 同様の傾向は福島県エリアでも見られるが，隆起（回 復）の速度はやや緩慢になる. 図-8に福島県での典型的 な例としていわき（観測点番号33）の回復過程を示す.

\section{(2) 曲線によるフィッティング}

2011年3月11日の本震の後, すぐに沈降から隆起に転
じるケースについて，曲線によるフィッティング (モデ ル化）を試みる.ここでは，2011年3月12日〜2015年3月 11日の間の観測值に対して，指数関数を用いてフィッテ イングを行うことにした.

$$
y=a_{1} \exp \left(-a_{2} t\right)
$$

ここで， $t$ は2011年3月12日からの通算日である， $a_{1}$ は 本震による沈下量に対応するパラメーターである. $a_{2}$ は地款変動からの回復の速度を制御するパラメーターで, 時定数の逆数に相当寸るパラメーターである.

図-9，10に指数関数によるフィッティングの結果の例 を示す. 指数関数によって矢本, いわきとも良好に近似 できていることがわかる.

\section{(3) 時定数の考察}

式(1)のパラメーター $a_{2}$ の逆数として定義される時定 数 $T=1 / a_{2}$ の值を表-1に追記する. 時定数 $T$ とは, $y の$ 值 が $a_{1}$ の $1 / e=0.368$ 倍になる時間のことであり，Tの值が小 さい方が回復の速度が速いことを意味する.

時定数の值は, 亘理で最も小さく651となっており, 概して，その他の值をみても宮城県南部で他地域より小 さい值となっている. 図-11に時定数と上下変動量の関 係を示す（表-1にはその具体的数值を示してある）．全 体的な傾向として, 沈下量そのものが大きかった場所で は回復（隆起）速度が小さく, 沈下量が小さい場所では 回復速度が大きいように見える.

\section{（4） 4年回復率の試算}

本震での沈降に対し，本震後 4 年でじれだけ沈降が回 復（隆起）したかを検討する。ここでは，本震後4年で の隆起量を本震時の沈降変位で除した值を 4 年回復率と 定義し, 試算してみた. 縦軸に検討対象地点の緯度を取 り，4年回復率を並べて表示したものが図-12である．大 きく沈降した宮城県中部地域の沿岸で回復率が大きくな っており，多くは $50 \%$ 以上回復しており場所により $100 \%$ 近く回復しているところもあることがわかる. 一方で, 福島県の方では回復の程度が小さく, また岩手県北部の 方では回復率がマイナスになっており, まだ本震以前の 高さまで回復していない場所があることがわかる.

なお，福島県南部において4年回復率がマイナスにな っている場所があるが，これは2011年4月11日の福島県 浜通りの余震（M7.0）でさらに大きく沈下したためであ る. 
表-1＼cjkstart東北地方太平洋岸の GEONET 観測点

\begin{tabular}{|c|c|c|c|c|c|c|c|c|}
\hline & 局名称 & 局番号 & $\begin{array}{l}\text { 緯度 } \\
\end{array}$ & 経度 & $\begin{array}{l}\text { データ } \\
\text { 有無 } \\
\end{array}$ & 回復過程 & 時定数 & $\begin{array}{l}\text { 本震沈下 } \\
\text { 量 }(\mathrm{cm})\end{array}$ \\
\hline 1 & 種市 & 950158 & 40.40520102 & 141.71313555 & O & 沈降 $\rightarrow$ 沈降 $\rightarrow$ 隆起 & - & 2.0 \\
\hline 2 & S洋野 & $07 \mathrm{~S} 063$ & 40.30213192 & 141.77685635 & $x$ & & & \\
\hline 3 & 久慈 & 940027 & 40.13344961 & 141.78909688 & $\bigcirc$ & 沈降 $\rightarrow$ 沈降 $\rightarrow$ 隆起 & - & 5.9 \\
\hline 4 & $\mathrm{~S}$ 普代 & $07 \mathrm{~S} 064$ & 39.99683975 & 141.92976988 & $x$ & & & \\
\hline 5 & 岩泉 1 & 950162 & 39.86937144 & 141.95054316 & 0 & 沈降 $\rightarrow$ 沈降 $\rightarrow$ 隆起 & - & 17.3 \\
\hline 6 & 田老 A & 111184 & 39.73583343 & 141.96714593 & $x$ & & & \\
\hline 7 & 宮古 & 940028 & 39.57238638 & 141.93996322 & 0 & 沈降 $\rightarrow$ 沈降 $\longrightarrow$ 隆起 & - & 34.1 \\
\hline 8 & 山田 & 950167 & 39.45816171 & 141.9552579 & 0 & 沈降 $\rightarrow$ 沈降 $\rightarrow$ 隆起 & - & 47.5 \\
\hline 9 & 釜石 & 950170 & 39.25351949 & 141.79804331 & 0 & 沈降 $\rightarrow$ 沈降 $\rightarrow$ 隆起 & - & 52.8 \\
\hline 10 & $\mathrm{~S}$ 大船渡 & 07S065 & 39.15787999 & 141.83514645 & $x$ & & & \\
\hline 11 & 大船渡 & 950171 & 39.02378273 & 141.73984737 & O & 沈降 $\longrightarrow$ 隆起 & 4306 & 74.0 \\
\hline 12 & P大船渡 & $02 \mathrm{P} 205$ & 39.01977567 & 141.75325344 & $x$ & & & \\
\hline 13 & S 陸前高田 & $07 \mathrm{~S} 066$ & 38.98620172 & 141.6697923 & $x$ & & & \\
\hline 14 & 気仙沼 & 950172 & 38.9028603 & 141.57259007 & 0 & 沈降 $\rightarrow$ 隆起 & 3214 & 64.2 \\
\hline 15 & $\mathrm{~S}$ 本吉 & $06 \mathrm{~S} 055$ & 38.79149631 & 141.49351739 & $x$ & & & \\
\hline 16 & 志津川 & 950175 & 38.6826995 & 141.44937147 & 0 & 沈降 $\longrightarrow$ 隆起 & 2384 & 67.2 \\
\hline 17 & S石巻北上 & 06S056 & 38.58552184 & 141.48689338 & $x$ & & & \\
\hline 18 & S石巻雄勝 & 06S057 & 38.49544152 & 141.53101174 & $x$ & & & \\
\hline 19 & 女川 & 940036 & 38.44919588 & 141.44116491 & $\mathrm{O}$ & 沈降 隆起 & 2912 & 87.5 \\
\hline 20 & S石巻牧浜 & 06S058 & 38.36419193 & 141.43466322 & $x$ & & & \\
\hline 21 & 牡鹿 & 960550 & 38.30118716 & 141.50068654 & O & 沈降 $\longrightarrow$ 隆起 & 4088 & $109.5^{*}$ \\
\hline 22 & S石巻 & $05 \mathrm{~S} 054$ & 38.26682646 & 141.47769205 & $x$ & & & \\
\hline 23 & 矢本 & 960549 & 38.42505902 & 141.21290907 & 0 & 沈降 $\longrightarrow$ 隆起 & 1392 & 48.5 \\
\hline 24 & $\mathrm{~S}$ 七ケ浜 & 06S059 & 38.2998 & 141.0636382 & $x$ & & & \\
\hline 25 & 利府 & 940037 & 38.31748761 & 140.95418509 & 0 & 沈降 $\longrightarrow$ 隆起 & 1454 & 28.2 \\
\hline 26 & 仙台太白 & 111185 & 38.19429452 & 140.91092655 & $x$ & & & \\
\hline 27 & 亘理 & 950179 & 38.02965947 & 140.84398903 & 0 & 沈降 $\longrightarrow$ 隆起 & 651 & 21.0 \\
\hline 28 & $\mathrm{P}$ 相馬 A & $14 \mathrm{P} 125$ & 37.8304361 & 140.961698 & $x$ & & & \\
\hline 29 & 相馬 1 & 940038 & 37.8006713 & 140.90808301 & 0 & 沈降 隆起 & 1858 & 29.3 \\
\hline 30 & $\mathrm{~S}$ 南相馬 A & $11 \mathrm{~S} 070$ & 37.636186 & 140.98359069 & $x$ & & & \\
\hline 31 & 小高 & 950203 & 37.53369315 & 141.00661087 & $x$ & & & \\
\hline 32 & 楢葉 A & 101181 & 37.26395759 & 140.9985426 & $x$ & & & \\
\hline 33 & いわき & 940041 & 37.09071452 & 140.90251546 & 0 & 沈降 $\longrightarrow$ 隆起 & 3698 & 47.3 \\
\hline 34 & いわき 2 & 970800 & 37.01844949 & 140.84164758 & 0 & 沈降 $\longrightarrow$ 隆起 & 4570 & 47.8 \\
\hline 35 & いわき 4 & 20946 & 36.93261998 & 140.69014981 & 0 & 沈降一隆起 & 49276 & 34.2 \\
\hline
\end{tabular}

*牡鹿の沈下量の計算では, 本震後, 4/8 までのデータがないため, 4/9の值で代用している

\section{4. 沈降からの回復過程の逐次予測}

以上の検討のように，本震で沈降し，その後，すぐに 隆起に転じた場所では，本震後4年間のデータを用いれ ば，回復 (隆起) 過程が指数関数によって良好に近似で きることがわかった．しかし，復興という観点からは， 本震後, できるだけ早い段階で回復（隆起）過程の予測 をできることが望ましい. あるいは, どの時点でその後 の隆起過程の予測が可能となるのかについて知見を得る 必要がある，そうすれば，それをもとに適切な岸壁のか さ上げ工事も可能になる。 このような目的に対する基礎
的知見を得るため, 本章では, 東北太平洋岸の観測点の うち, 本震で沈降後, すぐに隆起に転じた 12 点のうち, いわき4を除く11地点について，本震後の回復（隆起） 挙動の推定が概ね可能となる期間（月数）について考察 する.

\section{(1) 検討の方法}

沈降からの回復過程について, 指数関数によるフィッ ティングに用いる本震後のデータを 30 日 $\rightarrow 60$ 日 $\rightarrow 90$ 日の ように増やしていき，概ね一ケ月ごとの時定数の推移を みる. 前章での考察から時定数は本震後4年ではほぼ収 


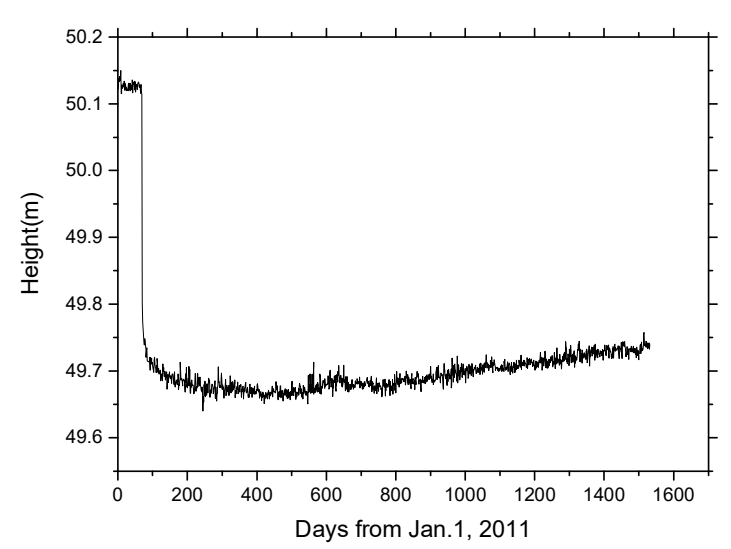

図-6 宮古の沈下回復過程

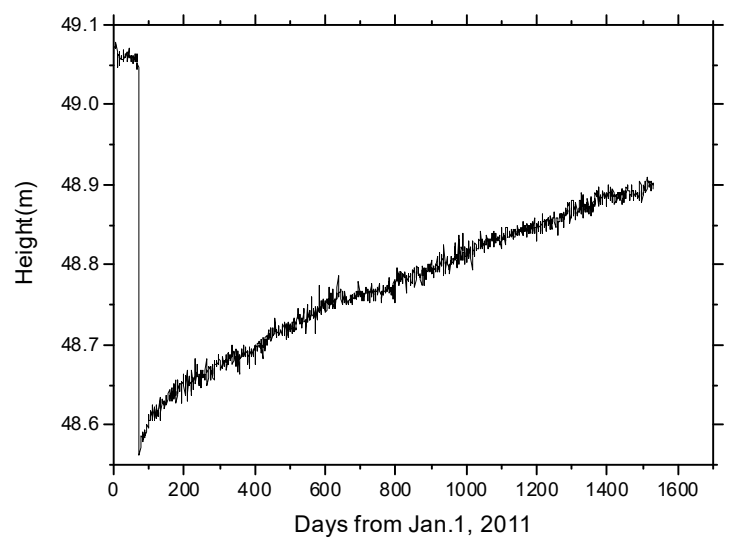

図-7 矢本の沈下回復過程

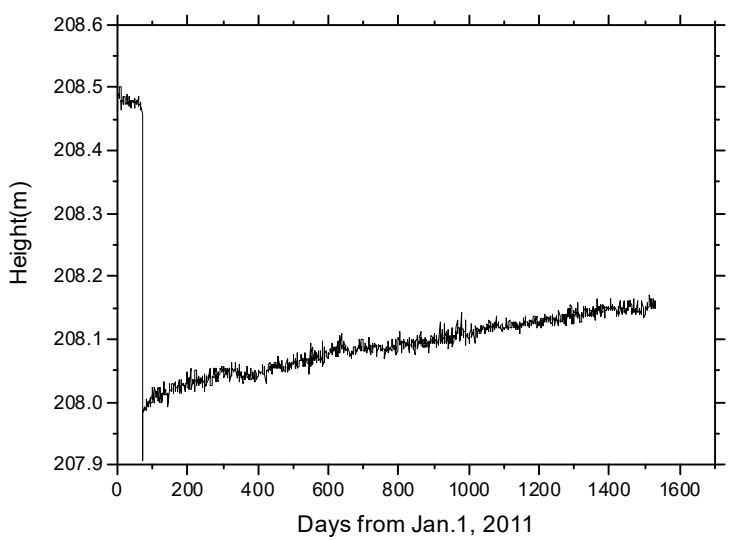

図-8 いわきの沈下回復過程

束していると考え，収束值に対し，10\%の誤差に収まる のに要する期間 (月数) を求めることにした.

なお， $a_{1}$ は本震による沈下量そのものに対応するの

で固定值で，ここでは時定数と関係する $a_{2}$ の值のみに 着目することになる.

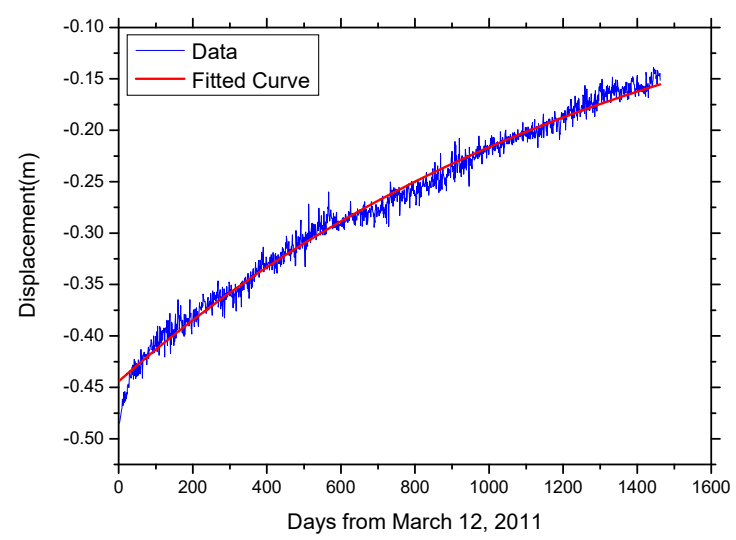

図-9 矢本の沈下回復過程の指数関数近似

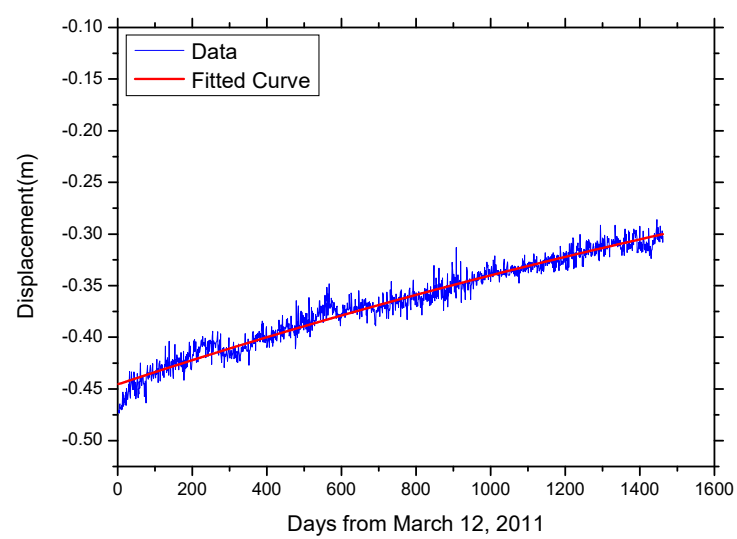

図-10 いわきの沈下回復過程の指数関数近似

\section{(2) 時定数の推移}

表-1において，沈降から隆起に転じた11地点について 時定数の推移を考察する. 図-13〜23には，本震後，30 日経過ごとに指数関数によりフィッティングを行った際 の時定数の值の推移を示したものである.この值がほぼ 一定值になった時，沈降からの回復挙動を概ね，指数関 数で表現できることになり，その後の地殻変動の推移の 予測が可能になる. なお，点線は時定数の収束值の土 10\%のラインを示したもので，この範囲に入った時，概 ね，収束したと考えた。例えば，大船渡では，約18ケ月 目で概ね，時定数が一定值（4306日）に近づき，それ以 降の地盤の挙動が推測可能となる.

表-2に11の検討地点について，時定数がほぼ一定にな る期間（月数）をまとめた，短くても11ヶ月，長い場合 には，36ケ月を要しており，指数関数によるモデル化が 可能である地点においても本震後，1～3年経過しないと その後の挙動予測は難しいことがわかった。ただし，各 時定数の推移を検討すると, いずれも本震後半年程度で 収束值に急速に近づく傾向が見られ，その後，いったん 大きくなりすぎたりする場合もあるが，ほぼ収束值に近 づいている. 今後, さらなる検討を加えることで，震災 
後, 約半年で回復（隆起）過程の予測がある程度実現可 能となる目途は得られた。

なお，本震で沈降後，さらに沈降が続くような場合に ついては，様々な取り組みが行われているものの，挙動 の予測が非常に難しく, 現時点での予測は困難であると 考えられる.

\section{(3) 地震後の変動過程の事例}

以上の検討は，現在のプレートカップリングが安定的 に推移すると仮定した場合に成り立つフィッティング結 果である. ここではプレート境界型の巨大地震の後の変 動過程について他の実例として, 1946年昭和南海地震 $(\mathrm{M}=8.0)$ の後の高知検潮所における潮位の変化と,

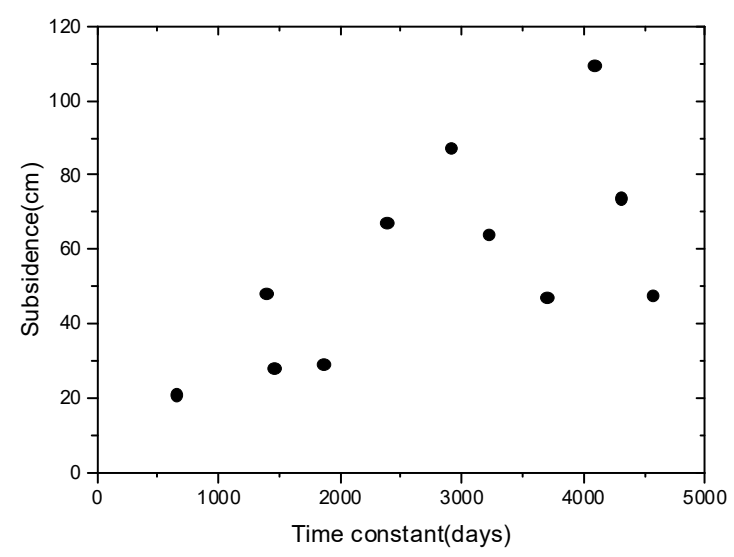

図-11 時定数と上下変動量の関係

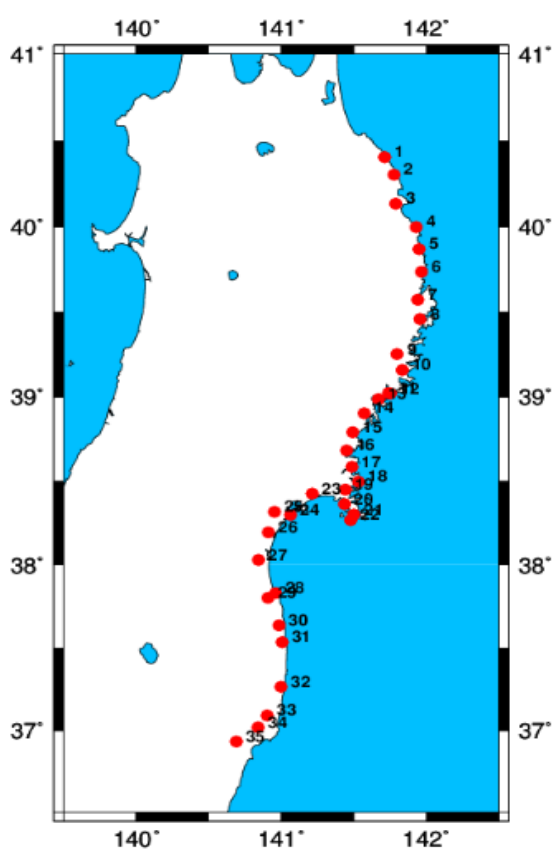

40.5

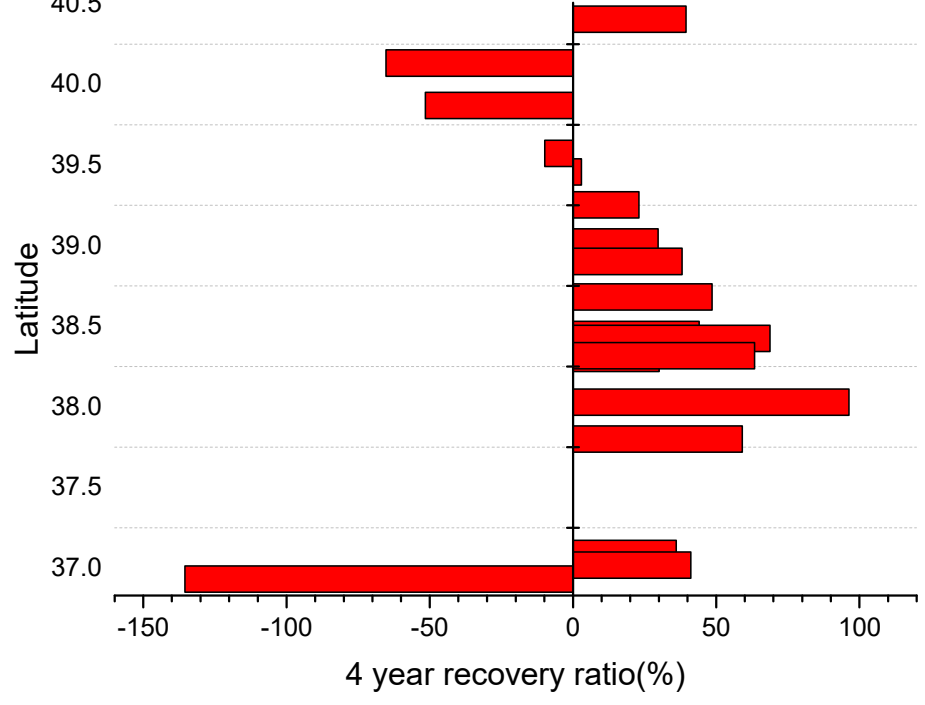

図-12４年回復率の比較
2003年十勝沖地震（M=8.0）の後のえりも2（局番号 960532）観測点における上下変動の推移を取り上げ，地 震後の変動過程の安定性について概観する.

まず昭和南海地震後の検潮記録の推移を図-24に示す. 地震が発生したのは1946年12月21日であるが，ここでは データが利用可能な1950年以降の17年間について，月平 均潮位記録 $(\mathrm{cm})$ の推移を示している（横軸は本震からの 通算月）。潮位を用いているため細かい変動はあるが全 体的には緩やかに潮位が低下，才なわち，陸地が緩やか に隆起していることがわかる.

もう1例として，図-25には，2003年9月26日に発生し た十勝沖地震について，2014年12月までの約12年間のえ りも2観測点の上下変動について示した（横軸は2003年1 月1日を起算日とする通算日）。本震で約 $20 \mathrm{~cm}$ 沈下した 後, 隆起に転じ, その後, 安定的に回復過程をたどって いることがわかる。

以上，2つの巨大海溝型地震の後の地盤の上下変動の 推移について概観したところ，ともに安定的な地盤変動 の推移が認められた．ただし，限定的な検証であるため， 今後, 検討事例を増やしていく必要がある. またプレー 卜間カップリングには地域性も関係してくるため, 地域 ごとに検討事例を増やし検証していくことが望ましい.

\section{5. まとめ}

2011年東北地方太平洋沖地震に伴う地殼変動からの回 


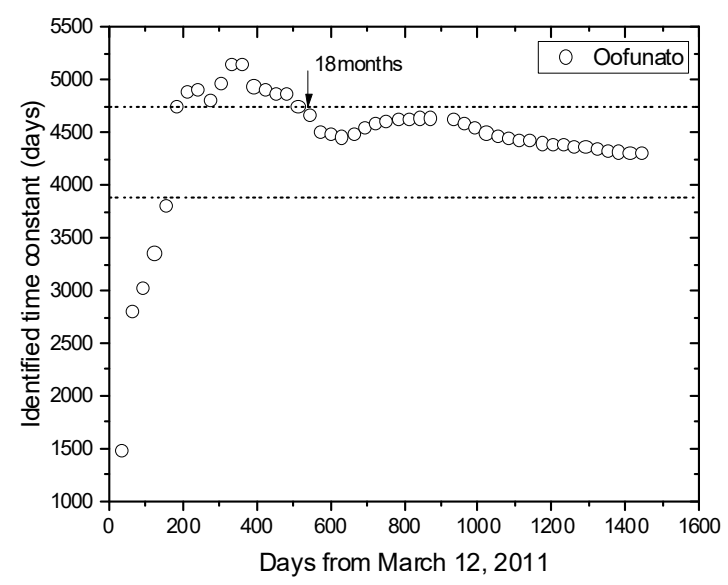

図-13 時定数の推移（大船渡）

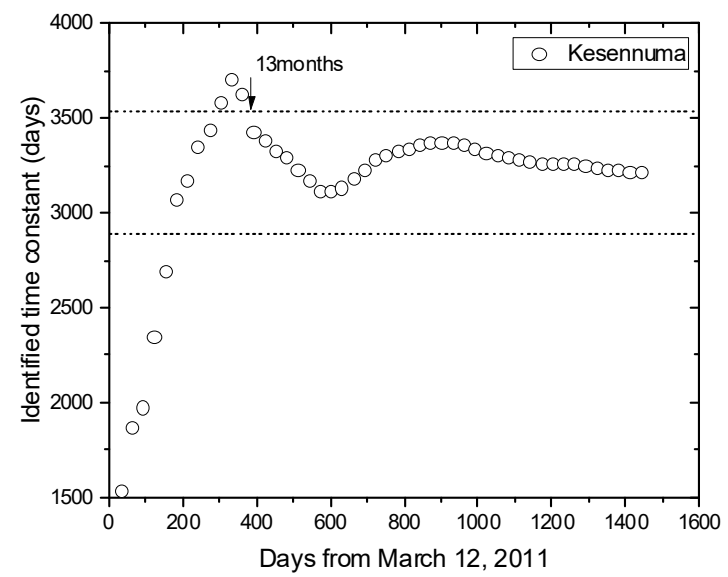

図-14 時定数の推移（気仙沼）

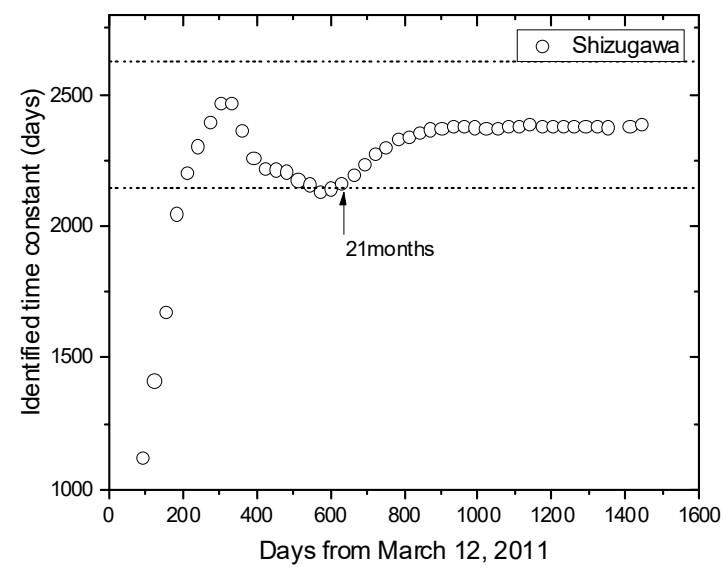

図-15 時定数の推移 (志津川)

復過程について，GEONETデータを用いて考察した。 2011年1月1日から本震の4年後である2015年3月11日まで の期間について，東北地方（岩手，宮城，福島県）の沿 岸部に設置されたGEONET観測点の挙動に着目した。岩 手県の北部地域では，本震による沈降の後，さらにしば らく沈降が続き，その後，隆起に転じるのに対し，岩手 県南部や宮城県, 福島県沿岸の観測点では，本震による

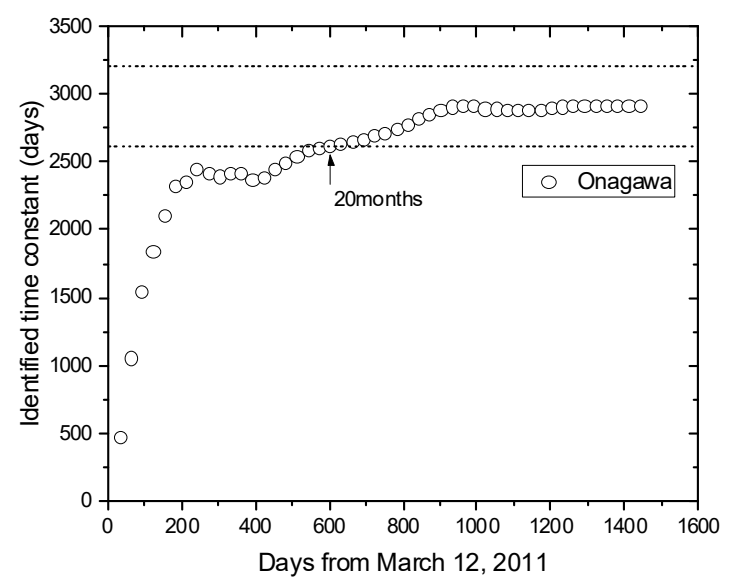

図-16 時定数の推移（女川）

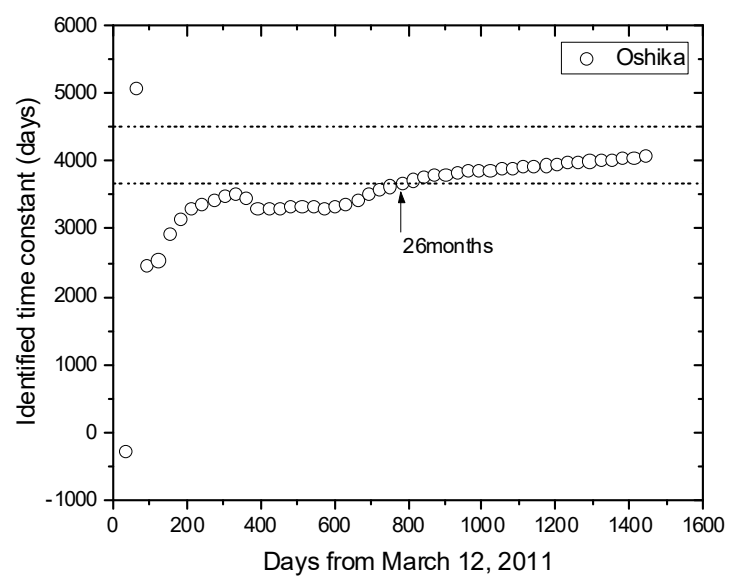

図-17 時定数の推移（牡鹿）

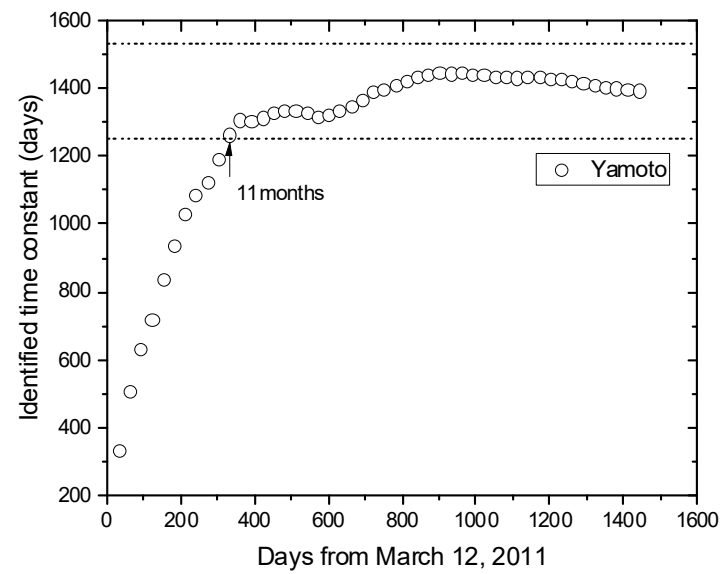

図-18 時定数の推移 (矢本)

沈降の後，すぐに隆起に転じる．回復（隆起）の速度は 宮城県で大きく，福島県では南部において隆起の速度が 緩慢である.

回復過程について指数関数によるフィッティングを行 ったところ，大変良くフィットすることがわかった．時 定数の值を調べると宮城県の亘理で最も小さい值となっ ており，そこから離れると大きい值になる傾向があるこ 


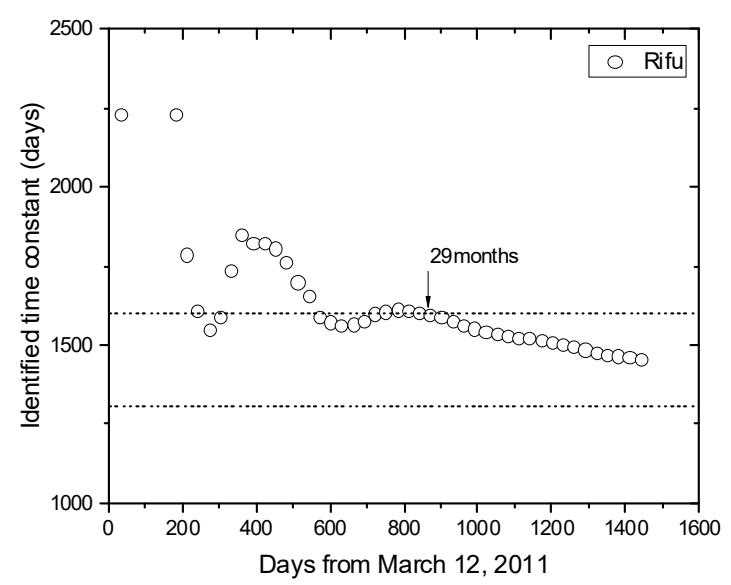

図-19 時定数の推移（利府）

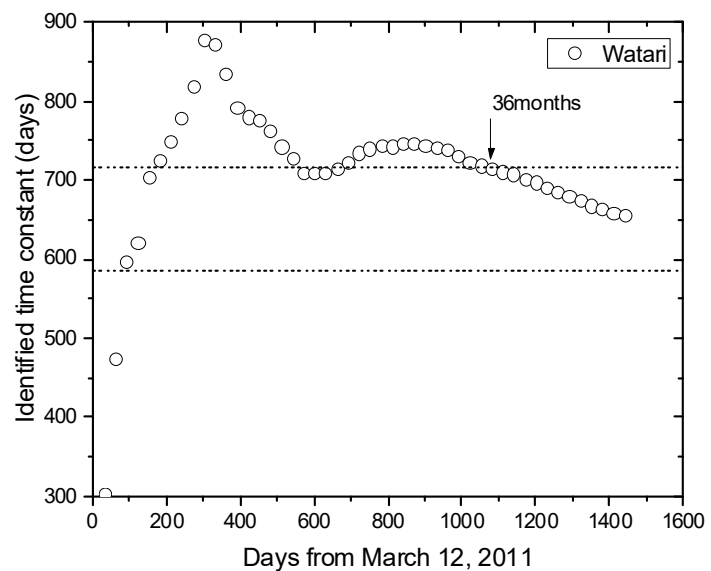

図-20 時定数の推移（亘理）

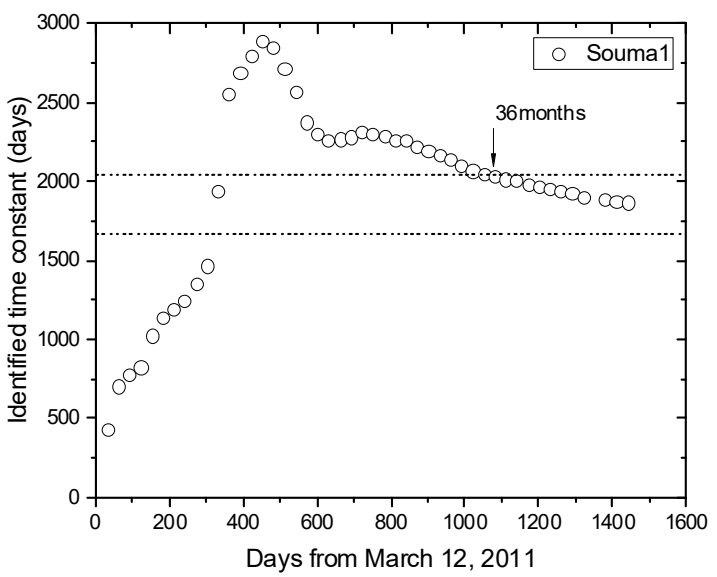

図-21 時定数の推移（相馬 1)

とがわかった．沈降後，すぐに隆起に転じる場合には， 指数関数を使って沈降からの回復（隆起）過程をモデル 化できることはわかったが，復興の観点からはその指数 関数の形状 (関数形) が本震後, どの時点で確定するの かが重要である，そこで，その形状を決める時定数の本 震後の推移を検討したところ，時定数が収束寸るために は概ね1年から3年を要することがわかった。一方で，本

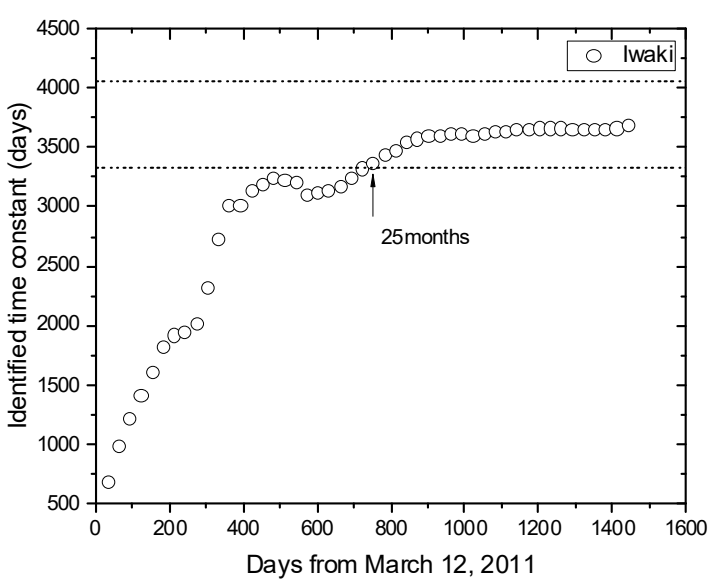

図-22 時定数の推移（いわき）

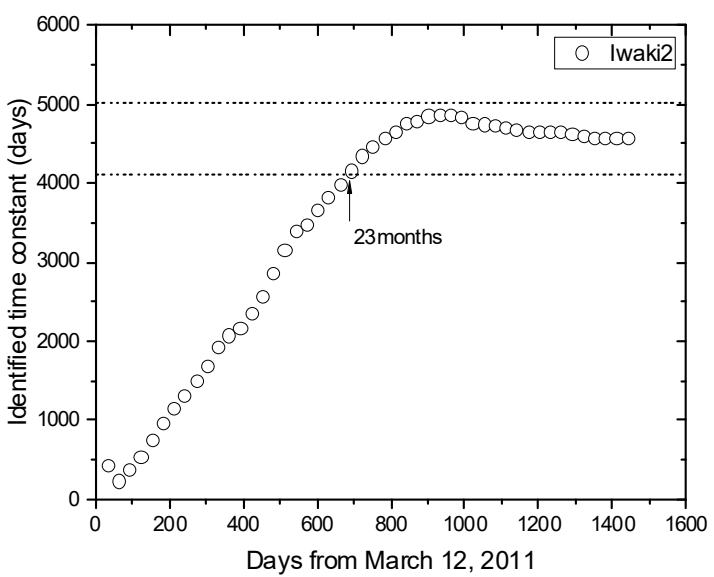

図-23 時定数の推移（いわき 2$)$

震後，半年程度で時定数は一旦収束值に近づき，その後， 変動しながら一定値に収束する傾向にあるので，地盤高 の将来予測のために，さらに検討ケースを増やし，検討 を重ねることで，本震後半年程度での地盤高の将来予測 が可能になる見通しは得られたものと考えている.

謝辞 : 本研究の一部は，一般社団法人四国クリエイト協 会による2015年度第19回「建設事業に関する技術開発・ 調查研究」支援事業による助成を受けたものです．また 国土地理院のGEONETデータ，気象庁の検潮記録を使用 させて頂きました。一部の図の作成にあたり Generic Mapping Toolsを用いました.ここに記して感謝の意を表 します.

\section{参考文献}

1) 日本経済新聞社：“三陸沿岸で地盤が隆起、漁業者 困惑「岸壁高すぎる」”，日本経済新聞（電子版） 記事, 2015 年 3 月 8 日。

2) 沢村武雄 : 南海大地震と地款運動, 高知大学学術研 究報告, 第 1 号, pp.1-14, 1951 .

3) 飛田幹男：対数・指数関数混合モデルによる東北沖 地震余効変動の予測実験, 日本地震学会講演予稿集, 
表-2 東北地方太平洋岸の GEONET 観測点

\begin{tabular}{|c|c|c|c|c|c|c|c|}
\hline & 局名称 & 局番号 & 緯度 & 経度 & 回復過程 & 時定数 & $\begin{array}{l}\text { 時定数がほぼ収 } \\
\text { 束するのに要し } \\
\text { た月数 }\end{array}$ \\
\hline 11 & 大大船渡 & 950171 & 39.02378273 & 141.73984737 & 沈降一隆起 & 4306 & 18 \\
\hline 14 & 気仙沼 & 950172 & 38.9028603 & 141.57259007 & 沈降一隆起 & 3214 & 13 \\
\hline 16 & 志津川 & 950175 & 38.6826995 & 141.44937147 & 沈降一隆起 & 2384 & 21 \\
\hline 19 & 女川 & 940036 & 38.44919588 & 141.44116491 & 沈降 $\rightarrow$ 隆起 & 2912 & 20 \\
\hline 21 & 牡鹿 & 960550 & 38.30118716 & 141.50068654 & 沈降 $\rightarrow$ 隆起 & 4088 & 26 \\
\hline 23 & 矢本 & 960549 & 38.42505902 & 141.21290907 & 沈降 $\rightarrow$ 隆起 & 1392 & 11 \\
\hline 25 & 利府 & 940037 & 38.31748761 & 140.95418509 & 沈降 $\rightarrow$ 隆起 & 1454 & 29 \\
\hline 27 & 亘理 & 950179 & 38.02965947 & 140.84398903 & 沈降一隆起 & 651 & 36 \\
\hline 29 & 相馬 1 & 940038 & 37.8006713 & 140.90808301 & 沈降 $\rightarrow$ 隆起 & 1858 & 36 \\
\hline 33 & いわき & 940041 & 37.09071452 & 140.90251546 & 沈降一隆起 & 3698 & 25 \\
\hline 34 & いわき 2 & 970800 & 37.01844949 & 140.84164758 & 沈降一隆起 & 4570 & 23 \\
\hline 35 & いわき 4 & 20946 & 36.93261998 & 140.69014981 & 沈降一隆起 & 49276 & - \\
\hline
\end{tabular}

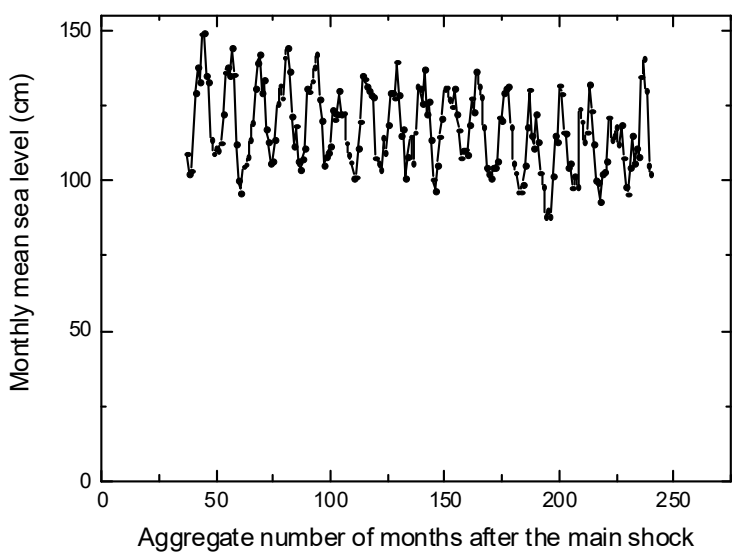

図-24 高知検潮所における月平均潮位の変化（1950年 1 月〜1966年 12 月)

S03-04, 2015.

4) Sun T., Wang K., Iinuma T., Hino R., He J., Fujimoto H., Kido M., Osada Y., Miura S., Ohta Y. and Hu Y.: Prevalence of viscoelastic relaxation after the 2011 Tohoku-oki earthquake, Nature, Vol.514, pp.84-87, 2014.

5) 宇津徳治, 嶋悦三, 吉井敏勊, 山科健一郎：地震の 事典[第 2 版], 朝倉書店, 2001 .

6) Kamiyama M., Sugimo M. and Kuse M.: Precursor of Crustal Movements Before the 2011 Great East Japan Earthquake, Proceedings of the International Symposium on Engineering Lessons Learnt from the 2011 Great East Japan Earthquake, pp.226-237, 2012.

7) 神山眞：地殼変動の回復の仮説モデル，個人通信,

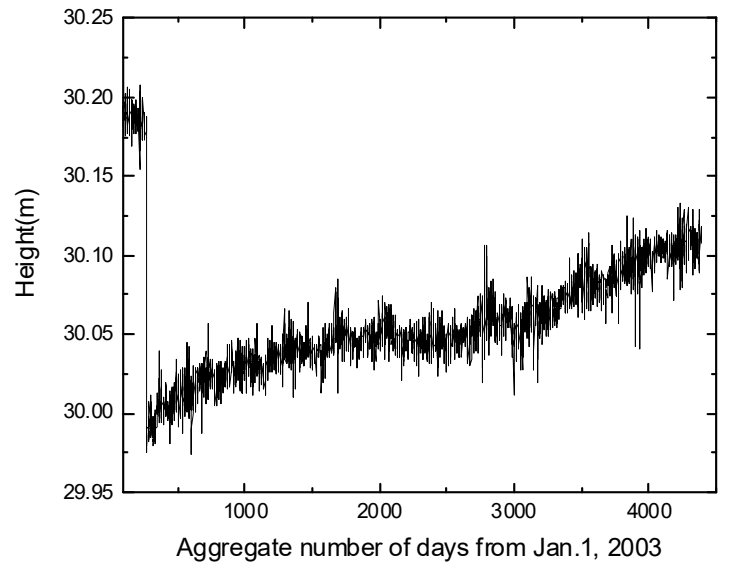

図-25

えりも 2 観測点における上下変動（2003 年 1 月〜 2014年 12月)

2015.

8) 東京大学地震研究所：地震研究所 NEWSLETTER Plus, No.14, 2011.

9) Wessel, P. and Smith W.H.F. : New improved version of the Generic Mapping Tools released EOS Trans. AGU, 79, 579, 1998.

10) Wessel, P. and Smith W.H.F. : Free software help map and display data, EOS Trans. AGU, 72, 441, 1991.

（2015.11.6受付，2016.1.25 修正，2016.2.20 受理） 


\title{
OBSERVATIONS OF RECOVERY PROCESS \\ FROM CRUSTAL MOVEMENT CAUSED BY \\ THE 2011 OFF THE PACIFIC COAST OF TOHOKU EARTHQUAKE
}

\begin{abstract}
Atsushi MIKAMI and Makoto KAMIYAMA
Due to noticeable subsidence of ground seen in a wide area of the Tohoku district caused by the 2011 off the Pacific coast of Tohoku Earthquake, port and harbor facilities became difficult to use as the sea level becomes too high during high tide. Necessary measures including level rising of quay walls were undertaken. However, subsequently, quay walls at some places became too high due to the increased ground elevation. A similar phenomenon was seen in Kochi city after the 1946 Showa Nankai Earthquake. People suffered from long lasting inundation there.

In order to obtain beneficial knowledge for the next predicted mega earthquake, this study observes recovery process from the crustal movement caused by the Tohoku Earthquake using GEONET data provided by the Geospatial Information Authority of Japan. Results showed that immediate ground elevation occurred after the subsidence at some areas while subsidence continued for a time after the main shock until level rising began at some other areas. For areas where immediate ground elevation occurred after the subsidence, recovery process from subsidence was described well with the fitting function of exponential decay type. However, 1 to 3 years amount of data after the main shock may be needed to identify the time constant which determines the shape of the exponential decay curve.
\end{abstract}

